\title{
Physiological and immune response of Litopenaeus vannamei undergoing the acute phase of the necrotizing hepatopancreatitis disease and after being treated with oxytetracycline and FF
}

\author{
Luis R. Martínez-Córdova ${ }^{1}$, Teresa Gollas-Galván ${ }^{2}$, Estefanía Garibay-Valdez ${ }^{1}$ \\ Rocío Valenzuela-Gutiérrez ${ }^{1}$, Marcel Martínez-Porchas ${ }^{2 *}$, Marco A. Porchas-Cornejo ${ }^{3}$ \\ Arturo Sánchez-Paz ${ }^{4} \&$ Fernando Mendoza-Cano ${ }^{4}$ \\ ${ }^{1}$ Departamento de Investigaciones Científicas y Tecnológicas de la Universidad de Sonora \\ Hermosillo, Sonora, México \\ ${ }^{2}$ Centro de Investigación en Alimentación y Desarrollo, Hermosillo, Sonora, México \\ ${ }^{3}$ Centro de Investigaciones Biológicas del Noroeste (CIBNOR), Unidad Guaymas, Guaymas, Sonora, México \\ ${ }^{4}$ Centro de Investigaciones Biológicas del Noroeste (CIBNOR), Laboratorio de Referencia, Análisis y \\ Diagnóstico en Sanidad Acuícola Los Angeles, Hermosillo, Sonora, México \\ Corresponding author: Marcel Martínez-Porchas (marcel@ciad.mx)
}

\begin{abstract}
The physiological and immune responses of adult shrimp (Litopenaeus vannamei) undergoing the acute phase of the necrotizing hepatopancreatitis (NHP) disease and the efficiency of oxytetracycline (OXI) and florfenicol (FF) to eliminate the pathogen were evaluated. Four shrimp groups were considered: three groups infected with necrotizing hepatopancreatitis bacteria (NHP-B) (two treated with antibiotics and a positive control) and one group non-infected (negative control). Hemolymph concentration of glucose, lactate, acylglycerides, cholesterol, total protein, aminotransferases, superoxide dismutase, and the transcriptional expression of several immune related genes were monitored at the acute phase of the disease, and at 15 and 20 days after administration of antibiotics (daa). Shrimp from the positive control registered a mortality of $100 \%$. NHP-B infection affected the immu-nophysiological response of shrimp; herein, most of the parameters were significantly up regulated in infected shrimp before the use of antibiotics, compared to the negative control. Increased transcriptional levels of clotting protein, lipopolysaccharide and $\beta$-1-3-glucan binding protein (LGBP), serine protease, peroxinectin, lysozyme, heat shock proteins (HSP) 60 and 70 were detected in shrimp treated with OXI. At 20 daa NHP-B was still detected in FF-treated shrimp, but not in OXI-treated shrimp. It is hypothesized that despite none of the antibiotics per se eliminated the bacterium, both had a negative effect on its virulence. OXI seems to have a greater effect, allowing shrimp to integrate a better immune response at 15 daa.
\end{abstract}

Keywords: Litopenaeus vannamei, gene expression, shrimp disease, necrotizing hepatopancreatitis, immune system, Rickettsia, intracellular pathogen, necrosis.

\section{Respuesta fisiológica e inmune de Litopenaeus vannamei durante la fase aguda de la enfermedad de la necrosis hepatopancreática y posteriormente tratado con oxitetraciclina y FF}

\begin{abstract}
RESUMEN. Se evaluaron respuestas fisiológicas e inmunes de camarones adultos (Litopenaeus vannamei) durante la fase aguda de la enfermedad de la necrosis hepatopancreática, y la eficacia de oxitetraciclina (OXI) y florfenicol (FF) para eliminar el patógeno causante de la enfermedad. Se consideraron cuatro grupos de camarones: tres grupos infectados con NHP-B (tratado con OXI, con FF y un control positivo) y un grupo no infectado (control negativo). Se monitoreó la concentración hemolinfática de glucosa, lactato, acilglicéridos, colesterol, proteína total, aminotransferasas, superóxido dismutasa (SOD), y la expresión de varios genes relacionados con el sistema inmune durante la etapa aguda de la enfermedad y 15 y 20 días después de la administración de antibióticos (dda). Los camarones del control positivo registraron una mortalidad de $100 \%$. La mayoría de los parámetros evaluados se incrementó en camarones infectados antes del uso de antibióticos. Al día 15 dda, lactato y SOD siguieron registrando altos niveles en ambos camarones tratados, mientras que se detectaron altos niveles de transcripción de proteína de coagulación, proteína unidora de lipopolisacáricos, serin proteasa, peroxidasa, lisozima y proteínas del choque térmico 60 y 70, en camarones tratados con OXI. Al día 20 dda NHP-B se siguió detectando en camarones tratados con FF, pero no en los tratados con OXI. Se sugiere
\end{abstract}


que aunque ninguno de los antibióticos per se eliminó a la bacteria, ambos tuvieron un efecto negativo sobre su virulencia. Además, es posible que OXI haya tenido un mejor efecto, permitiendo que los camarones integraran una mejor respuesta inmune a los 15 dda.

Palabras clave: Litopenaeus vannamei, enfermedad del camarón, necrosis hepatopancreática, sistema inmune, Rickettsia, patógeno intracelular.

\section{INTRODUCTION}

Because of its high tolerance to a wide range of environmental conditions, greater resistance to various diseases, and its excellent aquacultural performance, the Pacific white shrimp Litopenaeus vannamei is actually the most extensively farmed shrimp species worldwide. However, the global culture of this shrimp has recently faced serious problems, especially those related to the prevalence and severity of a number of viral and bacterial diseases (Lightner, 2011).

Vibrio-like species, as well as intracellular rickettsia-like organisms (RLO), are considered among the most important pathogens affecting shrimp health. Among the RLO diseases, that caused by the necrotizing hepatopancreatitis bacterium (NHP-B) is the most important affecting penaeids. Since its identification in 1985 as a shrimp pathogen, the NHP$\mathrm{B}$ has caused devastating economic losses to shrimp farming industry (Vincent \& Lotz, 2007), and mortalities over $95 \%$ have been reported.

Recent evidence has revealed that the transmission of the bacterium may occur either by horizontal or vertical pathways. The NHP-B has been detected associated with zooplankton samples from the Gulf of California (Mendoza-Cano et al., 2013); moreover, Avila-Villa et al. (2011), suggested that this pathogen has been associated to live feeds as Artemia.

The NHP-B is an intracellular RLO thriving in the cytoplasm of epithelial cells from hepatopancreas tubules. Previous studies have reported that once the host has been infected, it is practically unable to eradicate the pathogen without antibiotics, despite the response exhibited by the host's innate and non-specific immune system (Roch, 1999; Ávila-Villa et al., 2012). This immune response is constituted by cellular and humoral components, which jointly protect the host against invaders (Rendón \& Balcázar, 2003). However, this particular RLO has become a very aggressive pathogen since it affects the cells of a key organ in the physiology of shrimp, the hepatopancreas, causing a malfunction of the organ with the resulting physiological imbalances and followed by tissue necrosis.

The most evident clinical signs of the disease include a reduction in feeding activity, empty intestines, flaccid muscles and exoskeleton, the presence of epicomensals, darkened gills and pleopods, paleness and atrophy of hepatopancreas, and erratic swimming, among others (Vincent \& Lotz, 2005). The acute phase of the disease is observed 16-20 days after the infection, which is considered as the point of no return for infected organisms (Vincent \& Lotz, 2005); at this phase the use of antibiotics is almost indispensable to avoid massive mortalities.

Oxytetracycline (OXI) is probably the most used antibiotic worldwide to treat bacterial infections in aquatic organisms, mainly because of its acceptable effectiveness, low cost and acceptance by the international animal health control agencies. It is a wide-spectrum bacteriostatic compound produced by fungi (Streptomyces spp.), which is efficient against Gram positive and Gram negative pathogens as well as intracellular pathogens and it is used to treat systemic bacterial infections in aquacultural organisms (MoralesCovarrubias et al., 2012). OXI binds to the union site of the $30 \mathrm{~S}$ ribosomal subunit, inhibiting thus the protein translation process (Chopra \& Roberts, 2001). Tetracyclines have been used to eradicate diverse RLO in animals (Hussain et al., 2014)

Another antibiotic product used in the aquaculture industry, and approved by the FDA, is (FF), which is a structural analogue of chloramphenicol, but with a better antibacterial effectiveness; it is also considered as a wide-spectrum antibiotic including Gram positive and Gram negative bacteria, and inclusively intracellular bacteria such as RLO (Reda et al., 2013). FF penetrates into the cell through facilitated transport (Boxall \& Ericson, 2012), blocking the union site of the $50 \mathrm{~S}$ ribosomal subunit. However, despite the effectiveness of chloramphenicol analogues against RLO, the use of FF is not widespread in shrimp aquaculture.

This study aimed to evaluate the effectiveness of single recommended doses (COSAES) of OXI and FF on eradicating the NHP-B of the Pacific white shrimp, $L$. vannamei undergoing the acute phase of the disease, and to evaluate its physiological and immune responses before and after the use of antibiotics.

\section{MATERIALS AND METHODS}

\section{Experimental organisms}

Healthy juveniles of $L$. vannamei $(10 \pm 0.5 \mathrm{~g})$ were obtained from a commercial shrimp farm near to the 
laboratory facilities. Before acclimation shrimp were provided with OXI ( $3 \mathrm{mg} \mathrm{kg}^{-1}$ of shrimp biomass) during three consecutive days to eradicate any possible pathogen. Thereafter, shrimp were maintained for 15 days at a density of $40 \mathrm{org} \mathrm{m}^{-2}$ in plastic containers (80 L) with filtered seawater ( $\sim 35$ of salinity), continuous aeration (OD $\left.\geq 5 \mathrm{mg} \mathrm{L}^{-1}\right)$, water exchange ( $25 \%$ per day), constant temperature $\left(30^{\circ} \mathrm{C}\right)$, and supplementation of a commercial feed twice a day (4\% biomass/day; Purina, Mexico, 35\% crude protein). Subsequently, shrimp were diagnosed as free of bacterial and viral pathogens (NHP, EMS, IHHNV, TSV, WSSV) by molecular diagnostic tests in feces and hepatopancreas and intestine of randomly sacrificed organisms, by using the services of CIBNOR diagnostic laboratory.

\section{Bioassay}

Shrimp were divided into four groups and distributed in plastic aquaria at the same density considering three units per treatment. Three of the groups were infected with necrotizing hepatopancreatitis bacterium (NHP-B) by forced feeding with $40 \mu \mathrm{L}$ of a homogenate of hepatopancreas (1:1 w/v, hepatopancreas:glycerol) from shrimp confirmed as PCR positive to NHP-B (homogenate was confirmed as free of other pathogens as well). NHP-B strain was collected from a shrimp farm at Sonora, Mexico and reproduced in vivo in healthy shrimp. The fourth group was not infected (negative control) and NHP-B free homogenate was used for these shrimp.

Feeding inoculation was performed by using a micropipette adapted to a flexible plastic cannula that was inserted into the oral cavity, loading the required volume.

After infection, the organisms were maintained for 20 days under the above mentioned conditions to reach the acute phase of the disease. This period was established based on previous studies (Vincent \& Lotz, 2005) and experiences in our laboratory.

The success of the infection was confirmed by performing daily PCR to the DNA extracted from feces of the experimental shrimp. DNA was extracted by a commercial kit FastDNA ${ }^{\mathrm{TM}}$ Spin Kit (MP Biomedicals, USA).

Primers designed by Nunan et al. (2008) (Fwd: 5'CGT TGG AGG TTC GTC CTT CAG T-3' and Rv: 5'GCC ATG AGG ACC TGA CAT CAT C-3') were used to detect the presence of NHP-B under the following conditions: 1 cycle at $95^{\circ} \mathrm{C}$ during $5 \mathrm{~min}, 30$ cycles at $94^{\circ} \mathrm{C}$ for $30 \mathrm{~s}, 53^{\circ} \mathrm{C} / 30 \mathrm{~s}$ and $72^{\circ} \mathrm{C} / 1 \mathrm{~min}$ and a final cycle of $72^{\circ} \mathrm{C} / 5 \mathrm{~min}$ (Figueroa-Pizano et al., 2014). NHP-B was detected in all treatments (except the control) at $5^{\text {th }}$ day post infection.
After the 20 days period, the administration of antibiotics was initiated. One of the infected groups was treated with OXI (oxi-blend $®$ AQUA), the second with FF (flor-blend® AQUA) and the third was untreated (positive control). The dose was estimated considering the protocols performed by semi-intensive shrimp farms and $3 \mathrm{mg}$ of antibiotic/kg shrimp/day were used. Each antibiotic was dissolved into water + glycerol (1:1) mixture. The antibiotic mixture was applied to each group by force-feeding during three consecutive days. Shrimp from the positive and negative controls were fed with the water + glycerol mixture without the antibiotic.

Afterward, shrimp were maintained under controlled laboratory conditions during other 20 days. This period was considered as an additional time for the development of the disease in which all infected shrimp were supposed to be dead according to previous reports (Vincent \& Lotz, 2005; Ávila-Villa et al., 2012); in addition, the antibiotic would be eliminated by that time according to previous kinetic studies (Wang et al., 2004). Thus, survivors (if any) were sampled.

Hemolymph and hepatopancreas samples were extracted from ten individuals of each treatment (10 shrimp/replicate) after 20 days post-infection (before the use of antibiotics), and samples were also taken at $15^{\text {th }}$ and $20^{\text {th }}$ after the use of antibiotics. Hemolymph was utilized for the evaluation of biochemical parameters such as glucose, lactate, acylglycerides, cholesterol, and protein, enzymatic activities such as aspartate- and alanine-aminotransferases, superoxide dismutase and gene expression (details provided below). Hepatopancreas was exclusively used for the evaluation of gene expression.

The hemolymph was extracted from the base of the $5^{\text {th }}$ pereiopod using an insulin syringe $(1 \mathrm{~mL})$ containing $0.5 \mathrm{~mL}$ of cold anticoagulant $(10 \mathrm{mM}$ HEPES, $20 \mathrm{mM}$ EDTA, $10 \mathrm{mM} \mathrm{KCl}$ and $450 \mathrm{mM}$ $\mathrm{NaCl}$ ) (Vargas-Albores et al., 1993). Hemolymph samples were centrifuged at $800 \mathrm{x} g$ for $10 \mathrm{~min}$ at $4{ }^{\circ} \mathrm{C}$, and the precipitated hemocytes were used for gene expression analyzes, whereas the supernatant was used for the quantification of hemolymph metabolites. Hemocytes were suspended in $250 \mu \mathrm{L}$ of guanidine thiocyanate (TRI Reagent, SIGMA) and stored at $-20^{\circ} \mathrm{C}$ for further analyzes. The hepatopancreas was carefully dissected and divided into two longitudinal sections (vertical cut); one fragment was used for molecular diagnostic, and mixed with $250 \mu \mathrm{L}$ of lysis solution $(100 \mathrm{mM} \mathrm{NaCl}, 50 \mathrm{mM}$ Tris, $100 \mathrm{mM}$ EDTA, and 1\% SDS) and maintained at room temperature. The resting fragment was immediately mixed with $500 \mu \mathrm{L}$ of TRI Reagent and stored at $-20^{\circ} \mathrm{C}$ for further analyzes of gene expression. Samples were stored for five days and thawed at $4^{\circ} \mathrm{C}$. 


\section{Evaluation of hemolymph parameters}

The concentration of total protein was evaluated by the Biuret method adapted to microplate (HernándezLópez, 2001) and read at $550 \mathrm{~nm}$ using a Multiskan FC equipment (Thermo Scientific, USA).

The superoxide dismutase activity (SOD) was estimated by the commercial Kit Ransod (Randox, Crumlin, RU), based on the methods described by Liu et al. (2004) and Biagini et al. (1995), which consider the inhibition grade on the formation of the colorant formazan red by the reaction of 2-(4-iodophenyl)-3-(4nitrophenol)-5-phenyl tetrazolium (INT) chloride with the free superoxide radicals in the oxidation of xanthine catalyzed by xanthine oxidase.

The concentration of glucose, lactate, cholesterol, acylglycerides, and the activity of aspartate and analine-aminotrasferase (AST and ALT) were measured by the use of commercial kits (Randox Laboratories Ltd., USA) adapted to a microplate.

\section{Gene expression}

RNA was isolated from hepatopancreas and hemocytes. Samples were previously homogenized in a tissue homogenizer (FastPrep 5G, MP Biomedicals, USA) using plastic vials containing zirconium spheres (Lysing matrix A; MP Biomedicals, USA); after that, the guanidinium thiocyanate-phenol-chloroform method was used for the extraction (Chomczynski \& Sacchi, 2006). The concentration and purity of total RNA were determined spectrophotometrically in a NanoDrop ND8000 (Thermo, USA) at a wavelength of $260 \mathrm{~nm}$, considering only samples with a value near to 2 . DNA traces have been previously detected after the use of the above technique, using microfluidic DNA detections (Genomic and High Sensitivity DNA Screentape, Agilent, USA); however, any possible contamination with DNA was eliminated by treating the samples with DNase I (DNase I; Roche, Germany).

The synthesis of complementary DNA (cDNA) was performed with the enzyme reverse transcriptase following the specifications of a commercial kit and using $1 \mu \mathrm{g}$ of total RNA (QuantiTect Reverse Transcription Kit, Qiagen, USA).

The evaluation of gene expression by a quantitative PCR (qPCR) protocol was performed, and the method of relative quantification $2^{-\Delta \Delta} C_{\mathrm{T}}$ (Livak \& Schmittgen, 2001 ) was used. For the amplification and detection of specific fragments, the iTaq ${ }^{\mathrm{TM}}$ Universal SYBR Green Supermix (Biorad, USA) containing enhancers, stabilizers and a passive reference (ROX) was used in combination with the specific primers for each gene (Table 1). The qPCR reactions were done in a thermal cycler StepOnePlus ${ }^{\mathrm{TM}}$ Real-Time PCR System
(Applied Biosystems, USA) considering a final volume of $20 \mu \mathrm{L}$ for each reaction. The conditions of amplification and detection were: 1 cycle at $95^{\circ} \mathrm{C}$ for 5 min; 30 cycles at $94^{\circ} \mathrm{C}$ for $30 \mathrm{~s}$, at $60^{\circ} \mathrm{C}$ for $30 \mathrm{~s}$ and $72^{\circ} \mathrm{C}$ for $1 \mathrm{~min}$, and one final cycle at $72^{\circ} \mathrm{C}$ for $5 \mathrm{~min}$.

Gene expression or transcripts codifying for prophenoloxidase (proPO; $116 \mathrm{bp}$ ), transglutaminase (TGase; $150 \mathrm{bp}$ ), $\alpha$-2-macroglobulin ( $\alpha$-2-M; $204 \mathrm{bp}$ ) and peroxinectin (PE; $56 \mathrm{bp}$ ) were monitored in hemocytes; whereas clotting protein (CP; $169 \mathrm{bp}$ ), lipopolysaccharide-and $\beta$-1,3-glucan binding protein (LGBP; 64 bp), lysozyme (LYS; 126 bp) and serine protease (SP; $61 \mathrm{bp}$ ) were quantified in hepatopancreas. The expression of the heat shock proteins (HSP) 60 (138 bp), 70 (120 bp) and 90 (109 bp) was monitored in both, hemocytes and hepatopancreas. The constitutive gene $\beta$-actin (142 bp) was used as internal control or reference for all the selected genes; the constitutive expression of this gene was previously validated in organisms challenged with different doses of NHP-B inoculum. Efficiencies of the PCR reactions were calculated from the slope a standard curve derived from a dilution series (Efficiency 95-100\%). In addition, a melt curve analysis considering the interval $55-95^{\circ} \mathrm{C}$, with increments of $0.5^{\circ} \mathrm{C} \mathrm{min}^{-1}$, was performed to demonstrate the specificity of the PCR products.

\section{Statistical analysis}

After confirming that data were normal and homoscedastic, were analyzed by an analysis of variance, considering time and treatments as factors. Nonhomoscedastic or abnormal data were submitted to logtransformation. A Dunnett post-hoc analysis was performed for multiple comparisons between groups. A significance level of $P \leq 0.05$ was considered and the statistical software NCSS 7.0 was used.

\section{RESULTS}

\section{Infection}

The infection with NHP-B was successfully detected by PCR in all treatments (Table 2). The bacterium was not eliminated by the use of both OXI and FF and was still detected after 15 days of the administration of antibiotics (daa). NHP-B was still detected at 20 daa in shrimp treated with FF, but not detected in shrimp previously treated with OXI (Table 2). As expected, shrimp from the positive control registered a mortality of $100 \%$ at $22^{\text {th }}$ day from the infection.

\section{Hemolymph parameters}

Before the use of antibiotics the concentrations of glucose, lactate and AST in infected shrimp were signifi- 
Table 1. Primers used in the amplification of specific genes of white shrimp, Litopenaeus vannamei.

\begin{tabular}{|c|c|c|}
\hline Gene & Sequence of primers (5'-3') & $\begin{array}{l}\text { Accession } \\
\text { Number }\end{array}$ \\
\hline \multirow[t]{2}{*}{$\beta$-actin } & Fw 5'CCACGAGACCACCTACAAC3' & AF300705.2 \\
\hline & Rv 5’AGCGAGGGCAGTGATTTC3’' & \\
\hline \multirow[t]{2}{*}{ Prophenoloxidase } & Fw 5'GCCTTGGCAACGCTTTCA3' & EU373096.1 \\
\hline & Rv 5'CGCGCATCAGTTCAGTTTGT3' & \\
\hline \multirow[t]{2}{*}{ Transglutaminase } & Fw 5'TCGCCTCTGCACACGACACC $3^{\prime}$ & EU164849 \\
\hline & Rv 5'TCCACACGTCATTCCAAACGT3’ & \\
\hline \multirow{2}{*}{ a-2-macroglobuline } & Fw 5'GCACGTAATCAAGATCCG3' & EF073268 \\
\hline & Rv 5'CCCATCTCATTAGCACAAAC3' & \\
\hline \multirow[t]{2}{*}{ LGBP } & Fw 5'CATGTCCAACTTCGCTTTCAGA3' & EU102286.1 \\
\hline & Rv 5'ATCACCGCGTGGCATCTT3' & \\
\hline \multirow[t]{2}{*}{ Coagulation protein } & Fw 5'TGGCGTCACCGAAACCAACA3' & DQ984182 \\
\hline & Rv 5'RTGCCAGCGTGAGGAAAGCGA3' & \\
\hline \multirow[t]{2}{*}{ Peroxinectin } & Fw 5'TGGACCTCGCGGGAGAT3' & KC708021.1 \\
\hline & Rv 5'GACCGATAGCCACCATGCTT3' & \\
\hline \multirow{2}{*}{ Serine } & Fw 5'CGTCGTTAGGTTAAGTGCGTTCT3' & AY368151.1 \\
\hline & Rv 5'TTTCAGCGCATTAAGACGTGTT3’' & \\
\hline \multirow[t]{2}{*}{ Lysozyme } & Fw 5' TGGTGTGGCAGCGATTATGGCAAG3' & AF5394663 \\
\hline & Rv 5’ GCCCTTGTAGCGTTCGGTGTCG3' & \\
\hline \multirow[t]{2}{*}{ HSP 60} & Fw 5'TGCCAACAACACCAACGAAG3' & FJ710169.1 \\
\hline & Rv 5’GCCAACATAACTCCACGCCT3’' & \\
\hline \multirow[t]{2}{*}{ HSP 70} & Fw: 5'CTCCTGCGTGGGTGTGTT3' & AY645906.1 \\
\hline & Rv 5'GCGGCGTCACCAATCAGA3' & \\
\hline \multirow[t]{2}{*}{ HSP 90} & Fw 5'TGGGCTTCTACTCCGCCTACC3’' & HQ008268.1 \\
\hline & Rv 5'ACGGTGAAAGAGCCTCCAGCA3' & \\
\hline
\end{tabular}

Table 2. Detection of NHP-B in shrimp from the different treatments before and after the use of antibiotics (3 mg of antibiotic/kg shrimp/day). Results are expressed as positive or negative detection after PCR reaction.

\begin{tabular}{|c|c|c|c|c|c|c|}
\hline & Time & DNA sample & Negative control & Positive control & Oxytetracycline & FF \\
\hline Shrimp acclimation & Day 0 & Feces + shrimp hepatopancreas & Negative & Negative & Negative & Negative \\
\hline \multirow[t]{5}{*}{ Shrimp Infection } & Day 3 & Feces & Negative & Negative & Negative & Negative \\
\hline & Day 5 & Feces & Negative & Positive & Positive & Positive \\
\hline & Day 7 & Feces & Negative & Positive & Positive & Positive \\
\hline & Day 15 & Feces & Negative & Positive & Positive & Positive \\
\hline & Day 20 & Feces & Negative & Positive & Positive & Positive \\
\hline \multirow{5}{*}{$\begin{array}{l}\text { Antibiotic } \\
\text { administration }\end{array}$} & Day 0 & Feces + shrimp hepatopancreas & Negative & Positive & Positive & Positive \\
\hline & Day 5 & Feces & Negative & Dead organisms & Positive & Positive \\
\hline & Day 10 & Feces & Negative & Dead organisms & Positive & Positive \\
\hline & Day 15 & Shrimp hepatopancreas & Negative & Dead organisms & Positive & Positive \\
\hline & Day 20 & Shrimp hepatopancreas & Negative & Dead organisms & Negative & Positive \\
\hline
\end{tabular}

cantly higher $(P<0.05)$ compared to the negative control, whereas the concentration of cholesterol, was significantly lower in the infected shrimp (Fig. 1). In particular, glucose increased by $\geq 450 \%$, lactate $\geq 400 \%$ and AST $\geq 300 \%$ in infected shrimp compared to the negative control.

After the use of OXI and FF, no significant differences $(P>0.05)$ at any sampling time $\left(15^{\text {th }}\right.$ or $20^{\text {th }}$ daa) were detected for any hemolymph parameter regarding the negative control (except for SOD and
AST) (Fig. 1). SOD activity was significantly higher in shrimp previously treated with OXI at $15^{\text {th }}$ and $20^{\text {th }}$ daa, and AST was significantly higher in shrimp treated with FF at $20^{\text {th }}$ daa (Fig. 1).

\section{Gene expression}

Up-regulation of proPO and $\alpha-2-\mathrm{M}$ was detected in hemocytes of NHP-B-infected shrimp before the use of antibiotics (Fig. 2). However, the number of proPO transcripts decreased at 15 and 20 daa of both antibio- 

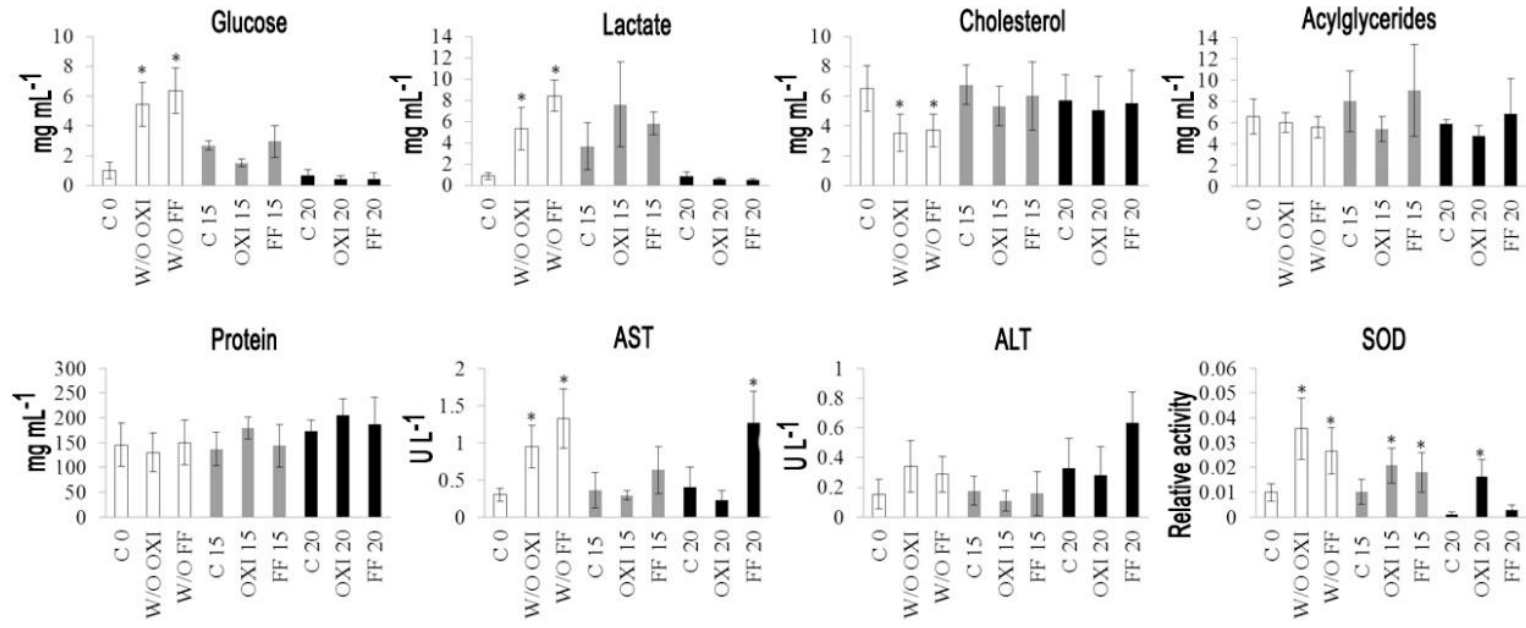

Figure 1. Concentration of hemolymph parameters in NHP-B infected shrimp before (W/O OXI and W/O FF), and 15 and 20 days after the use of OXI (OXI 15 and OXI 20) and FF (FF 15 and FF 20). Shrimp considered as negative control for each sampling date is expressed as "C". AST: aspartate aminotransferase, ALT: alanine aminotransferase, SOD: superoxide dismutase. Non-infected shrimp were considered as negative control ( $\mathrm{C} 0, \mathrm{C} 15$ and $\mathrm{C} 20)$. Asterisks indicate gene up regulation, whereas vertical bars indicate standard deviation.
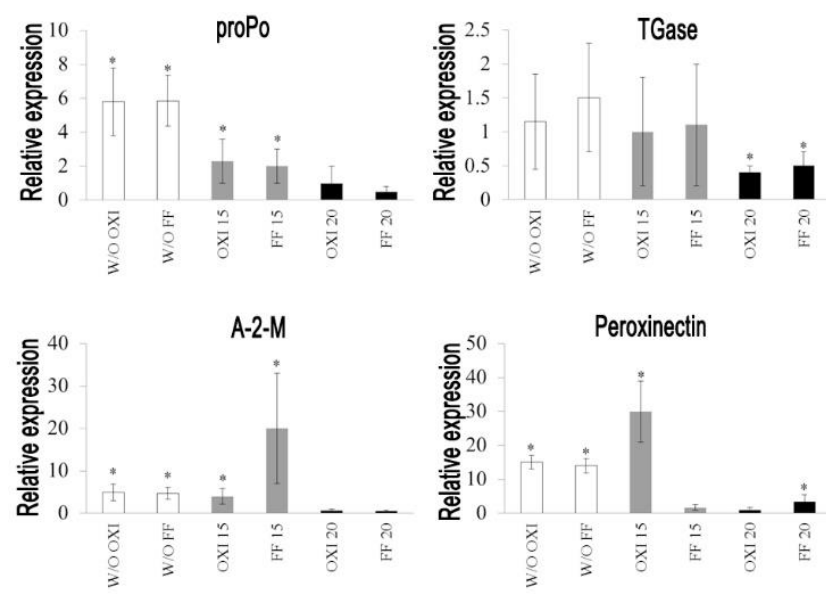

Figure 2. Relative expression (respect to $\beta$-Actin) of prophenoloxidase (proPO), transglutaminase (TGasa), $\alpha$ 2-macroglobuline and peroxidase in hemocytes of shrimp infected with NHP-B before being treated with oxytetracycline (W/O OXI) or FF (W/O FF), and after 15 and 20 days from being treated with both OXI (OXI 15 and OXI 20) and FF (FF 15 and FF 20). Non-infected shrimp (control group, C 0, C 15 and C 20) with a relative value of 1 . Asterisks indicate gene up regulation, whereas vertical bars indicate standard deviation.

tics, although the over transcription continued at 15 daa (Fig. 2). The $\alpha-2-\mathrm{M}$ remained up-regulated at 15 daa in organisms treated with OXI ( $\sim 3$ fold-times), but the transcription level was significantly higher ( 20 foldtimes) in shrimp medicated with FF. At 20 daa the transcription levels of $\alpha-2-\mathrm{M}$ were down-regulated to those detected in the negative control.
Peroxinectin was also up-regulated (15 fold times) in the infected shrimp before the use of antibiotics and remained highly expressed (30 fold) in shrimp treated with OXI at 15 daa (Fig. 2).

No changes in the expression of TGase were observed in hemocytes of shrimp infected with NHP-B and neither after being treated with both antibiotics; however, a decline in the number of transcripts was recorded at 20 daa for shrimp treated with both antibiotics (Fig. 2).

Up-regulation of CP, LGBP, SP and lysozyme genes from hepatopancreatic tissue was observed in infected shrimp before the use of the antibiotics (Fig. 3 ). The transcription levels of these genes (except for lysozyme) was significantly increased in shrimp treated with OXI at 15 daa, whereas no transcriptional regulation was recorded in shrimp treated with FF (except for lysozyme up-regulation). At 20 daa no overtranscription was detected for the genes monitored in shrimp treated with OXI (except for LGBP upregulation), whereas lysozyme was up-regulated in shrimp treated with FF (Fig. 3).

Regarding transcription of heat shock proteins, a significant over-expression of HSP60 was detected in hemocytes and hepatopancreas ( $\sim 30$ and $\sim 80$ fold-times respectively) of shrimp infected with NHP-B before being treated with antibiotics (Fig. 4). At 15 daa the transcription levels of HSP60 remained up-regulated in hemocytes of shrimp treated with both antibiotics; however only shrimp medicated with OXI registered an up-regulation in hepatopancreas at 15 daa. At 20 daa, the transcription levels of HSP60 in shrimp treated with 


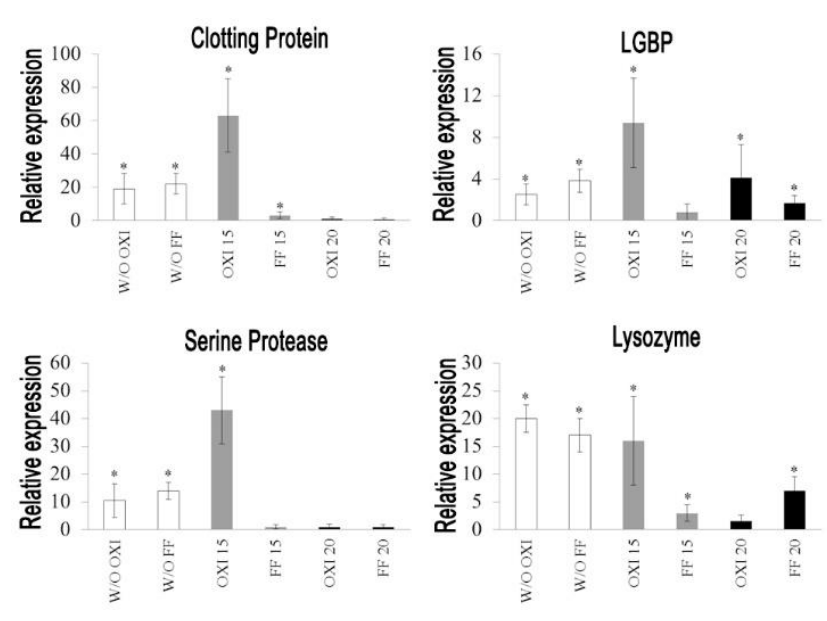

Figure 3. Relative expression (respect to $\beta$-Actin) of coagulation proteins, lipo-polysaccharides and $\beta$-glucan binding protein (LGBP), serine and lysozyme in hepatopancreas of shrimp infected with NHP-B without being treated with oxytetracycline (W/O OXI) or FF (W/O $\mathrm{FF}$ ), and after 15 and 20 days from being treated with both OXI (OXI 15 and OXI 20) and FF (FF 15 and FF 20). Noninfected shrimp (control group, C 0, C 15 and C 20) with a relative value of 1 . Asterisks indicate gene up regulation, whereas vertical bars indicate standard deviation.

both antibiotics decreased to similar levels of those observed in negative controls (Fig. 4). HSP70 was regulated at lower scale compared to HSP60; no transcription changes were detected for HSP70 in hepatopancreas before and after the use of antibiotics. However, up-regulation was detected in shrimp hemocytes before and after the use of antibiotics, except in shrimp previously medicated with $\mathrm{FF}$ at 15 daa (Fig. 4).

Finally, the transcription of HSP90 was upregulated in the hepatopancreas of shrimp infected with NHP-B before the use of antibiotics. At 15 daa a similar up-regulation was observed for both groups (Fig. 4). However, no over transcription was detected at 20 daa for shrimp previously treated with OXI.

\section{DISCUSSION}

The high concentrations of plasmatic glucose and lactate observed in NHP-B infected shrimp before the administration of antibiotics suggest an alteration in the metabolism of infected shrimp, which suggests an activation of anaerobic pathways to compensate the high energy demand necessary to achieve an effective immune response. Similar metabolic alterations have been observed in L. vannamei during the course of infection with a strain of the Gram-negative bacteria Vibrio campbellii. An slight, but significant, accumu-

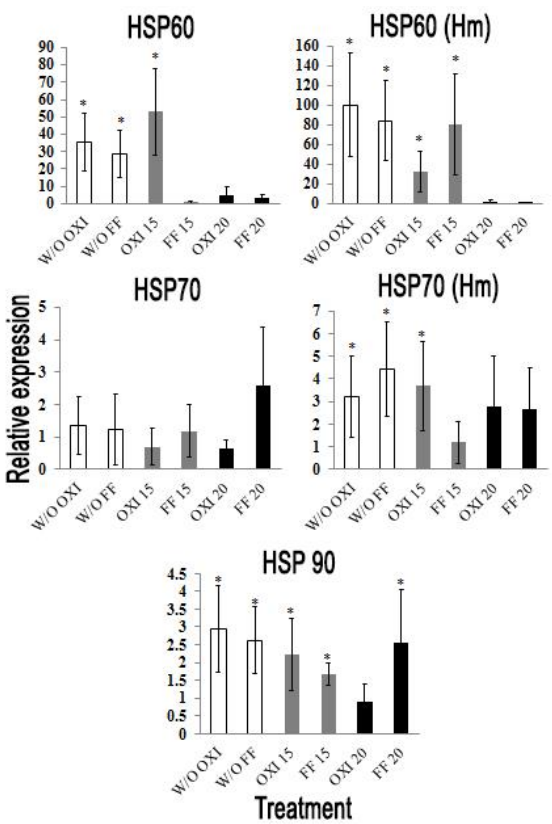

Figure 4. Relative expression (respect to $\beta$-Actin) heat shock proteins 60 (HSP60), 70 (HSP70) y 90 (HSP90) in hepatopancreas and hemocytes of shrimp infected with NHP-B without being treated with oxytetracycline (W/O $\mathrm{OXI}$ ) or FF (W/O FF), and after 15 and 20 days from being treated with both OXI (OXI 15 and OXI 20) and FF (FF 15 and FF 20). Non-infected shrimp (control group, C 0 , C 15 and C 20) with a relative value of 1 . Asterisks indicate gene up regulation, whereas vertical bars indicate standard deviation.

lation of lactate was found in Vibrio-injected shrimp, which suggests that the normal metabolism may be altered to meet the energy requirements to accomplish the immune response against the bacterial infection, leading to depression of oxygen due to an increased consumption and a consequent shift to anaerobic metabolism, resulting in increasing concentrations of lactate (Scholnick et al., 2006). These responses suggest an altered physiological response of shrimp, probably because of the action of the pathogen and the consequent damage in the hepatopancreas.

The increase of AST activity indicates a possible damage in the hepatopancreatic tissue, considering that these enzymes are incorporated to the hemolymph after cellular lysis occurs in any organ (Najafabadi et al., 1992). The decline in the cholesterol levels of infected shrimp could be associated with a starving condition and/or to impaired absorption of this nutrient from the supplemental feed since it cannot be synthesized de novo by this species. Previous reports have documented empty stomachs in shrimp confirmed as positive to this pathogen (Ávila-Villa et al., 2012). Moreover, empty intestines were observed in shrimp undergoing the acute phase of the disease. 
In addition, NHP-B infection caused an effect over SOD activity levels. This parameter can be considered as an indicator of stress in aquatic organisms and as an indirect indicator of the activation of the immune response. Besides being one of the main antioxidant defense pathways in response to oxidative stress, SOD promotes the generation of immunoproteins (Fridovich 1995; Campa-Córdova et al., 2002). Microbiocidal metabolites generated by the immune response can also be harmful to the host; thus antioxidant mechanisms such as the generation of SOD are used by the cell to convert the excess of these metabolites into hydrogen peroxide that passes freely through membranes. The antioxidant superoxide dismutase (SOD) converts this microbiocidal metabolite into hydrogen peroxide whereas catalase and glutathione peroxidase remove the hydrogen peroxide from cells (Campa-Córdova et al., 2002). The observed elevation of SOD in this study may be associated to the activation of the immune response in shrimp challenged with NHP-B while the elevated SOD activity at 15 daa in shrimp treated with both antibiotics suggests that shrimp may have elicited a protective immune response against the pathogen. Most of the SOD responses in penaeid shrimp have been studied after the use of immunosimulators; however, Ji et al. (2009) reported up-regulation of SOD in $L$. vannamei after being challenged with pathogenassociated molecular patterns.

The up-regulation of $\alpha-2-\mathrm{M}$, proPO and peroxinectin genes seems as a plausible evidence of the participation of hemocytes in the immune response of shrimp against NHP-B, considering that $\alpha-2-\mathrm{M}$ impedes the union of proteases with their substrates and it can affect serine-, aspartate-, cysteine- and metalproteases, either from the pathogens or the host (Armstrong 2006, 2010). Additionally, $\alpha-2-\mathrm{M}$ is considered a regulator of the proPO system which, in its active form (PO), participates in the melanization process of pathogens and damaged tissues. In addition, peroxinectin communicates through hemocytes to activate phagocytosis, encapsulation and nodule formation (Lu et al., 2006).

The activation of $\mathrm{CP}$ is dependent from the action of TGase (Maningas et al., 2008). This is a key factor in the gelling process of hemolymph because the cross joint of their molecules forms stable clots (Morales \& Cuéllar-Anjel, 2008). There was a significant overexpression of the CP and LGBP transcriptions observed in hepatopancreas of infected shrimp. The presence of minute amounts of compounds of microbial origins, such as $\beta$-1,3-glucans, activates the immune response while LGBP participates in the recognition of these molecules (Cerenius \& Söderhäll, 2004). There is ample evidence that these molecules are capable of triggering the proPO-activating system in crustaceans.

The immune response of infected shrimp was also observed in the hepatopancreas, indicated by the upregulation of serine protease (an enzyme that activates the proPO system), (Sritunyalucksana et al., 2001), and lysozyme (an antibacterial protein which hydrolyzes peptidoglycans from invader cells).

Finally, the immune response included the upregulation of heat shock proteins in hemocytes and hepatopancreas. The higher up-regulation level of HSP60 compared to HSP70 and HSP90 could be associated to the fact that the first is involved in the innate immune response of crustaceans, while HSP60 is a mitochondrial protein playing a role in the folding process of key proteins after import into the mitochondria (Huang et al., 2011). The chaperone activity of this protein is involved in the major roles of defense against pathogen infection and response to stress.

The immune system of crustaceans is not a linear process, but a complex network which includes hundreds of interconnections (Johansson \& Soderhall, 1989). Evidence of the activation of this network was detected when shrimp was infected with NHP-B. However, the immune system of shrimp per se has been reported as incapable to eliminate NHP-B, and only delays the death of organisms if antibiotics are not used (Ávila-Villa et al., 2012).

Despite none of the antibiotics were capable to eradicate the bacteria, the high survival observed in the treated organisms $(\geq 80 \%)$ compared to the positive control (100\% of mortality) indicates a positive effect of both antibiotics; probably because antibiotics diminished the virulence of the bacteria or decreased the bacterial load, allowing shrimp to exhibit the immune response to cope with the infection during the trial.

Hemolymph parameters at 15 and 20 daa suggest that the stress level of shrimp decreased after the use of both antibiotics; however, the immune response remained active at 15 daa in hemocytes of shrimp medicated with both antibiotics; but particularly in the hepatopancreas of shrimp treated with OXI. Herein, the absence of NHP-B in shrimp treated with OXI at 20 daa, suggest that the use of the antibiotic and the posterior increase of the immune response (either in hemocytes and hepatopancreas) contributed to the control of the pathogen, probably affecting its development and diminishing its virulence. Herein, tetracycline and its analogs have demonstrated to inhibit proteinases of Gram-negative bacteria (Imamura et al., 2001). 
In addition, there is evidence suggesting that subinhibitory concentrations of antibiotics (including FF) interfere with microbial adherence to host cells (Blickwede et al., 2004), affecting thus the capacity of the pathogen to colonize any particular host. Despite only one antibiotic concentration was tested in this experiment, there is evidence to conclude that it was a sub-inhibitory concentration; however, further research is required to have more precise data about inhibitory and lethal concentrations.

The diminished pathogenicity of NHP-B exposed to OXI could provide the time required for shrimp to mount an effective immune response against this pathogen; for instance, a more efficient immune response and higher resistance against pathogens has been recorded in shrimp previously challenged with non- or low-pathogenic agents, which suggests the existence of a "specific immune memory" in crustaceans, including shrimp (Johnson et al., 2008).

Although none of the two antibiotics fully eradicated the NHP-B at these particular doses, it seems logical that OXI had a greater negative effect on the lifecycle of the pathogen, which allowed shrimp to "fight back" the disease. Besides the OXI mode of action, its better antibiotic effect, when compared to FF, could be hypothetically explained by the penetration mode of both antibiotics into the cells. OXI penetrates the cells by simple diffusion and facilitated transport (active efflux from cell), whereas FF penetrates exclusively by facilitated transport (reduced uptake into cell) (Davies \& Webb, 2003). However, in spite of the resistance of shrimp treated with OXI, the noncomplete elimination of the bacteria represents a potential risk of developing antibiotic resistance by the pathogen such as has been documented in some other cases (Rebouças et al., 2011; Gao et al., 2012).

On the other side, the use of FF is a not allowed in some countries, because it is a fluorinated derivative of chloramphenicol, which may cause adverse effects on human health. In this context, OXI could be a better option in the treatment against NHP-B. However, it is necessary to take in consideration that FF is much safer than chloramphenicol, due to the substitution of the nitro-group attached to the benzene ring, by a sulphomethyl group (Khalil et al., 2012). Despite the above, the perception of sanitary authorities, which regulate some practices in aquaculture, remains negative for the utilization of FF. Although the occurrence of NHP-B has been cleared by using OXI and FF from shrimp, the doses administrated so far are extremely high (6 and $1 \mathrm{~g} \mathrm{~kg}^{-1}$ of shrimp respectively) and are unacceptable for shrimp aquaculture, because of the elimination of these antibiotics to the environment and because of potential risks to human health due to the consumption of shrimp with high concentrations of antibiotics in shrimp tissue. In this context, the use of natural products with antibacterial activity may be an adequate alternative considering that shrimp can withstand NHP-B infections if the pathogenicity of the bacterium is negatively affected, as hypothetically occurred during the trial.

\section{ACKNOWLEDGEMENTS}

Special thanks to Consejo Nacional de Ciencia y Tecnología (CONACYT) for the financial support for this experiment allowed to project 168614; convocatoria de Ciencia Básica.

\section{REFERENCES}

Armstrong, P. 2006. Proteases and protease inhibitors: a balance of activities in host-pathogen interaction. Immunobiology, 211: 263-281.

Armstrong, P. 2010. Role of $\alpha 2$-macroglobulin in the immune responses of invertebrates. Invertebr. Surv. J., 7: 165-180.

Ávila-Villa, L., D. Fimbres-Olivarria, G. García-Sánchez, T. Gollas-Galván, J. Hernández-López \& $\mathrm{M}$. Martínez-Porchas. 2012. Physiological and immune responses of white shrimp (Litopenaeus vannamei) infected with necrotizing hepatopancreatitis bacterium. Aquaculture, 324: 14-19.

Avila-Villa, L., M. Martínez-Porchas, T. Gollas-Galván, J. López-Elías, L. Mercado, Á. Murguia-López, F. Mendoza-Cano \& J. Hernández-López. 2011. Evaluation of different microalgae species and Artemia (Artemia franciscana) as possible vectors of necrotizing hepatopancreatitis bacteria. Aquaculture, 318: 273-276.

Biagini, G., D. Sala \& I. Zini. 1995. Diethyldithiocarbamate, a superoxide dismutase inhibitor, counteracts the maturation of ischemic-like lesions caused by endothelin-1 intrastriatal injection. Neurosci. Lett., 190: 212-216.

Blickwede, M., P. Valentin-Weigand \& S. Schwarz. 2004. Subinhibitory concentrations of FF enhance the adherence of FF-susceptible and FF-resistant Staphylococcus aureus. J. Antimicrob. Chemother., 54: 286288.

Boxall, A. \& J. Ericson. 2012. Human pharmaceuticals in the environment. Springer, New York, pp. 63-83.

Campa-Córdova, A., N. Hernández-Saavedra \& F. Ascencio. 2002. Superoxide dismutase as modulator of immune function in American white shrimp (Litopenaeus vannamei). Comp. Biochem. Physiol. C: Toxicol. Pharmacol., 133: 557-565. 
Cerenius, L. \& K. Söderhäll. 2004. The prophenoloxidaseactivating system in invertebrates. Immunol. Rev., 198: 116-126.

Chomczynski, P. \& N. Sacchi. 2006. The single-step method of RNA isolation by acid guanidinium thiocyanate-phenol-chloroform extraction: twentysomething years on. Nat. Protoc., 1: 581-585.

Chopra, I. \& M. Roberts. 2001. Tetracycline antibiotics: mode of action, applications, molecular biology, and epidemiology of bacterial resistance. Microbiol. Molec. Biol. Rev., 65: 232-260.

Davies, J. \& V. Webb. 2003. Antibiotic resistance in bacteria. Desk Encyclop. Microbiol., 3: 25-46.

Figueroa-Pizano, M.D., A.B. Peregrino-Uriarte, G.M. Yepiz-Plascencia, M. Porchas-Martínez, T. GollasGalván \& L.R. Martínez-Cordova. 2014. Gene expression responses of white shrimp (Litopenaeus vannamei) infected with necrotizing hepatopancreatitis bacterium. Aquaculture, 420-421: 165-170.

Fridovich, I. 1995. Superoxide radical and superoxide dismutases. An. Rev. Biochem., 64: 97-112.

Gao, P., D. Mao, Y. Luo, L. Wang, B. Xu \& L. Xu. 2012. Occurrence of sulfonamide and tetracycline-resistant bacteria and resistance genes in aquaculture environment. Water Res., 46: 2355-2364.

Hernández-López, J. 2001. Diseño de técnicas para la cuantificación de moléculas plasmáticas de camarón, Tesis Doctorado en Ciencias, CIBNOR, La Paz, 49 pp.

Huang, W.-J., J.-H. Leu, M.-T. Tsau, J.-C. Chen \& L.L.Chen. 2011. Differential expression of LvHSP60 in shrimp in response to environmental stress. Fish Shellfish Immunol., 30: 576-582.

Hussain, T., M. Jamal, F. Nighat \& S. Andleeb. 2014. Broad spectrum antibiotics and resistance in nontarget bacteria: an example from tetracycline. J. Pure Appl. Microbiol., 8: 2667-2671.

Imamura, T., K. Matsushita, J. Travis \& J. Potempa. 2001. Inhibition of trypsin-like cysteine proteinases (Gingipains) from Porphyromonas gingivalis by tetracycline and its analogues. Antimicrob. Agents Chemoter., 45: 2871-2876.

Ji, P.-F., C.-L. Yao \& Z.Y. Wang. 2009. Immune response and gene expression in shrimp (Litopenaeus vannamei) hemocytes and hepatopancreas against some pathogen-associated molecular patterns. Fish \& Shellfish Immunol., 27: 563-570.

Johansson, M. \& K. Soderhall. 1989. Cellular immunity in crustaceans and the proPO system. Parasitol. Today 5: 171-176.

Johnson, K., M. Van Hulten \& A. Barnes. 2008. Vaccination of shrimp against viral pathogens: phenomenology and underlying mechanisms. Vaccine, 26: 4885-4892.
Khalil, S., E. Hamed \& O. Hassanin. 2012. Residue withdrawal of FF from the serum and edible tissues of broiler chickens. J. Am. Sci., 8: 514-524.

Lightner, D. 2011. Virus diseases of farmed shrimp in the Western Hemisphere (the Americas): a review. J. Invertebr. Pathol., 106: 110-130.

Liu, C.-H., S.-T. Yeh, S.-Y. Cheng \& J.C. Chen. 2004. The immune response of the white shrimp Litopenaeus vannamei and its susceptibility to Vibrio infection in relation with the moult cycle. Fish Shellfish Immunol., 16: 151-161.

Livak, K. \& T. Schmittgen. 2001. Analysis of relative gene expression data using real-time quantitative PCR and the 2-CT method. Methods, 25: 402-408.

Lu, K.-Y., Y.-T. Huang, H.-H. Lee \& H.H. Sung. 2006. Cloning the prophenoloxidase cDNA and monitoring the expression of proPO mRNA in prawns (Macrobrachium rosenbergii) stimulated in vivo by $\mathrm{CpG}$ oligodeoxynucleotides. Fish Shellfish Immunol., 20: 274-284.

Maningas, M.B., H. Kondo, I. Hirono, T. Saito-Taki \& T. Aoki. 2008. Essential function of transglutaminase and clotting protein in shrimp immunity. Molec. Immunol., 45: 1269-1275.

Mendoza-Cano, F., A. Sánchez-Paz, T. Encinas-García, D. Galván-Álvarez, D. Coronado-Molina \& J. Hernández-López. 2013. First record of necrotizing hepatopancreatitis bacterium (NHP-B) associated with the zooplankton samples from the Gulf of California, Mexico. Mar. Biodivers. Rec., 6: e85.

Morales, V. \& J. Cuéllar-Anjel. 2008. Guía técnicaPatología e inmunología de camarones peneidos. Programa CYTEC Red II-D Vannamei. Panamá, 253 pp.

Morales-Covarrubias, M., L. Tlahuel-Vargas, I. MartínezRodríguez, R. Lozano-Olvera \& J. Palacios-Arriaga. 2012. Necrotising hepatobacterium (NHPB) infection in Penaeus vannamei with FF and oxytetracycline: a comparative experimental study. Rev. Cient., 22: 7280.

Najafabadi, A.K., R. Ellender \& B. Middlebrooks. 1992. Analysis of shrimp hemolymph and ionic modification of a Penaeus cell culture formulation. J. Aquat. Anim. Health, 4: 143-148.

Nunan, L., C. Pantoja \& D. Lightner. 2008. Improvement of a PCR method for the detection of necrotizing hepatopancreatitis in shrimp. Dis. Aquat. Organ., 80: 6973.

Rebouças, R.H., O.V. de Sousa, A.S. Lima, F.R. Vasconcelos, P.B. de Carvalho \& R.H.S. dos Fernandes-Vieira. 2011. Antimicrobial resistance profile of Vibrio species isolated from marine shrimp farming environments (Litopenaeus vannamei) at Ceará, Brazil. Environ. Res., 111: 21-24. 
Reda, R., R. Ibrahim, E.-N. Ahmed \& Z. El-Bouhy. 2013. Effect of oxytetracycline and $\mathrm{FF}$ as growth promoters on the health status of cultured Oreochromis niloticus. Egyptian J. Aquat. Res., 39: 241-248.

Rendón, L. \& J. Balcázar. 2003. Inmunología de camarones: conceptos básicos y recientes avances. Rev. AquaTIC, 19: 27-33.

Roch, P. 1999. Defense mechanisms and disease prevention in farmed marine invertebrates. Aquaculture, 172: 125-145.

Scholnick, D., K. Burnett \& L. Burnett. 2006. Impact of exposure to bacteria on metabolism in the penaeid shrimp Litopenaeus vannamei. Biol. Bull., 211: 44-49.

Sritunyalucksana, K., K. Wongsuebsantati, M. Johansson \& K. Söderhäll. 2001. Peroxinectin, a cell adhesive protein associated with the proPO system from the black tiger shrimp, Penaeus monodon. Develop. Comp. Immunol., 25: 353-363.

Received: 26 November 2015; Accepted: 14 April 2016
Vargas-Albores, F., M. Guzmán \& J. Ochoa. 1993. An anticoagulant solution for haemolymph collection and prophenoloxidase studies of penaeid shrimp (Penaeus californiensis). Comp. Biochem. Physiol. PT. A, 106: 299-303.

Vincent, A. \& J. Lotz. 2005. Time course of necrotizing hepatopancreatitis (NHP) in experimentally infected Litopenaeus vannamei and quantification of NHPbacterium using real-time PCR. Dis. Aquat. Organ., 67: 163-169.

Vincent, A. \& J. Lotz. 2007. Advances in research of necrotizing hepatopancreatitis bacterium (NHPB) affecting penaeid shrimp aquaculture. Rev. Fish. Sci., 15: 63-73.

Wang, W., H. Lin, C. Xue \& J. Khalid. 2004. Elimination of chloramphenicol, sulphamethoxazole and oxytetracycline in shrimp, Penaeus chinensis following medicated-feed treatment. Environ. Int., 30: 367-373. 